\title{
Complex Interdisciplinary Approach to Modelling Information Literacy Education
}

\author{
Tibor Koltay \\ ORCID 0000-0003-0548-7527 \\ Independent Researcher \\ Budapest, Hungary \\ Enikő Szőke-Milinte \\ ORCID 0000-0002-6493-6778 \\ Vitéz János Institute of Teacher Training \\ Pázmány Péter Catholic University, Budapest, Hungary
}

\begin{abstract}
Purpose/Thesis: This paper identifies the most important theoretical issues and frameworks that may serve as a basis for models of teaching information literacy.

Approach/Methods: The paper reviews relevant subject literature published between 1990s and the present to outline the disciplinary context of information literacy in order to identify concepts that might be used to model teaching of information literacy.

Results and conclusions: In the light of convergences and overlaps between different literacies, this paper considers various pedagogic approaches - phenomenographic, sociocultural, and discourse analytical, to combine them with the cognitive approach to information literacy. The literature review shows that all these approaches might contribute to a theoretical foundation of information literacy across different age groups and on different levels of education.

Originality/Value: Teaching information literacy is examined from a cross-disciplinary perspective with a focus on information science and pedagogy.
\end{abstract}

\section{Keywords}

Cognitive approach. Discourse analytical approach. Information literacy. Information science. Pedagogy. Phenomenography. Sociocultural approach.

Received: 14 April 2020. Reviewed: 18 June 2020. Revised: 12 September 2020.

Accepted: 26 September 2020.

\section{Introduction}

Information literacy (IL) is a core subject and one of the most common topics in information science (IS) (also referred to as library and information science) (Pinto et al., 2013). However, our understanding of information literacy might be furthered by attending to its relation to teaching and learning as well as varied types of literacy (Onyancha, 2020).

For the purposes of this study, information science was defined in the following terms:

- It is a field of study concerning human recorded information;

- It focuses on the components of the information chain; and 
- It is based on a long-standing perspective as well as more up-to-date insights (Robinson, 2009).

Information literacy is a research area and a field of practice and expertise for information professionals at the same time (ALISE, 2016). It concerns disciplines other than IS; as such, while it is not its exclusive preserve (Onyancha, 2020). This becomes clear in an analysis of research papers on IS, in which IL features frequently (Dora \& Kumar, 2019). IL is not restricted even to the social sciences, as it is a research interest of 27 disciplines (Onyancha, 2020). This makes clear that there is a need for investigating how the outcomes of different studies, targeting IL can be harmonized with each other (Bruce, 2016).

\subsection{Convergences that define theory}

New literacy theories, stemming from the "ideological" model of literacy which accounts for the increasing multiplicity and integration of significant (textual, visual, audio, spatial, or behavioral) modes of meaning-making (New London Group, 1996). This model marks the appearance of radically different approaches that portray literacy as a social practice consisting of a potentially endless number of different literacies (multiliteracies), sharing in the same time a holistic view of literacy, related to empowerment and community building (Street, 1984).

In our information-intensive world, the process of acquiring information literacy requires an understanding of numerous possible ways of interacting with information and media, without forgetting about the implications of such behaviors (Materska, 2014).

Information literacy also follows the developments of varied information environments (Koltay et al., 2016). These changes are reflected in the most current definition of IL articulated by CILIP (2018):

Information literacy is the ability to think critically and make balanced judgements about any information we find and use. It empowers us as citizens to develop informed views and to engage fully with society.

This definition confirms the importance of empowerment, and moves away from a simplistic understanding of IL as a set of skills for finding, evaluating and using information (Secker, 2018). It also emphasizes IL's relation to print, data, images, and the spoken word. It also acknowledges the overlaps between IL and digital literacy, as well as media literacy (CILIP, 2018). This perception is in conformity with the idea that the convergences between varied literacies of the information age are decisive for its present and future development.

\subsection{Other approaches}

Today, we see clearly that the convergences between different forms of media and information and communication technologies (ICTs) (Livingstone et al., 2008) have been followed by other convergences between information literacy, media literacy and other literacies, also shaping their terminologies.

As a result of these convergences, IL and media literacy overlap and complement each other as they are meant to foster the same skills, while addressing different information constructs (Lau, 2013), even though there is no consensus regarding the boundaries and territories of these two literacies (Lee \& So, 2014). 
When defining digital and media literacy in the media-saturated, information-rich society, Hobbs (2010) listed various skills, of which two in particular demonstrate the effect of the abovementioned convergences. The first skill is knowing how to make responsible choices when accessing, comprehending, and sharing information and ideas. The second, closely related one is knowing how to analyze messages by identifying their author(s), purpose and point of view, and evaluating the quality and credibility of their content. It is necessary to develop these competencies both over the course of formal education as well as in informal settings, as without these competencies no one can be said to be literate.

The above convergence is also recognized by broad definitions of media literacy which go beyond specific formats. They emphasize primary skills, such as critical thinking, and social skills. These primary skills can then be adapted to specific media developments (Pfaff-Rüdiger \& Riesmeyer, 2016).

All these arguments posit that there is a common ground between media literacy and information literacy, and this convergence is also acknowledged by the idea of metaliteracy, which is a comprehensive framework that informs other literacy types of the digital age (Mackey \& Jacobson, 2011).

The emergence of the concept of data literacy is a result of the recent technological developments which enabled computers to generate and handle large quantities of data. Data literacy is also an outcome of the convergences mentioned above both in regard to recent technological developments and to varied literacies, as it shares several features with other literacies, especially information literacy (Koltay, 2015).

It is feasible to recognize that information theory and the theory of learning also are converging, especially if we accept the longstanding view that learning with information is authentic learning, and that IL is indispensable for successful learning (AASL, 1998). In other words, we can count with the absorption of information literacy by the educational disciplines (Bawden, 2015). In this context, it can also be said that IL is both an object of teaching and an object of learning (Limberg et al., 2012).

We also have to acknowledge the persisting need for adjusting the properties of IL to the digital environment, underlined among others by Špiranec and Banek Zorica (2010). It is particularly important, as the concept of IL originally was dominated by questions of access, because it had been dealing with media which was not always easily accessible (Livingstone et al., 2008). However, now we deal with the overabundance of information, and require new concepts, such as information overload, to think with (Bawden \& Robinson, 2009).

\section{Constructivist approaches to IL}

Despite considerable advances in the field of IS, a unified theory of IL is still lacking (Špiranec et al., 2016). Clarifying the relationship between research and practice also continues to be a challenge (Aharony et al., 2017). Although we witness a constant expansion of scholarship, which reflects empirically and theoretically grounded research, produced within the fields of information science and educational science, the theoretical foundations of IL remain vague (Pilerot, 2016). The following section partially redresses this lack.

If we want to go beyond the view of information users as lacking skills and knowledge, it is crucial to combine IL theory with pedagogical approaches (Limberg et al., 2012). 
Undoubtedly, a pluralistic approach is required for such a development of IL theory, so it should not be restricted to teaching information handling skills only. On the other hand, we must be aware of the importance of these skills which make the level of information literacy of our students measurable.

According to Bruce (1997), constructivist views can be contrasted with behaviorist approaches, based on measurable characteristics of being information literate. Nonetheless, while acknowledging the affordances of constructivist views, she argues that they fail to adequately define characteristics exhibited by individuals. Considering this, the Bruce's relational model maps IL onto the different ways of experiencing it. The experiential nature of learning is tangible insofar as it involves continuous building, amending and eventually transforming previous knowledge structures (Walton \& Cleland, 2017).

In any constructivist view, information literacy is more than the ability to engage successfully with codified forms of knowledge; it also facilitates knowing of an information landscape (Lloyd, 2006). Information landscapes are communicative spaces, created by people who co-participate in a field of practice (Lloyd, 2010). They are the "context" in which information is described (Whitworth, 2014). They define ways of knowing central to the construction of someone's individual agency and intersubjectivity relating to the common reference points and knowledge shared by people who are collectively engaged in a common endeavor or practice (Lloyd, 2017).

Many new approaches to IL take a constructivist approach to teaching and learning by highlighting the experiential and empowering nature of the learning process. Constructivist approaches represent a clear turn from the neutral and linear view of skills deployment, questioned by several information science scholars and information literacy professionals (see e.g. Marcum, 2002; Webber \& Johnston, 2000).

In the following sections of this paper, we will focus on three constructivist approaches, discussed by Limberg, Sundin and Talja (2012), who use phenomenographic and sociocultural theories, explicitly grounded in theories of learning, and discourse analytical approaches providing a broader historical and sociological perspective to these theories.

\subsection{Phenomenographic approaches}

Phenomenography defines learning as an activity of constructing meaning, without classifying learning experiences as right or wrong. Accordingly, phenomenographic approaches do not focus on a transfer of knowledge from teacher to student, but on the importance of understanding the learners' perspective (Limberg et al., 2012).

At the core of phenomenographic research are participants' experiences. As a consequence, whatever the premises of a given study, it seeks to find out not only why something happens, but also to inquire how experiences evolve and what the participants do and how they feel about it (Morrison \& Secker, 2017).

Phenomenographic studies show that IL can take on a range of meanings within any group of information users. Applying phenomenography produces a complete picture of a given knowledge domain and knowledge-based capacities (Forster, 2016).

The "seven faces" model of information literacy, developed by Bruce (1997) is also rooted in research, basing on phenomenography. Although originally conceived for use in the 
higher education - in our opinion - it may be also used in the education of schoolchildren. This model identifies following skills and abilities:

- being able to use ICTs for seeking and communicating information;

- seeking and finding information sources;

- executing information seeking processes;

- organizing and controlling information;

- building a knowledge base in a new area of interest;

- working with knowledge and personal perspectives for novel insights; and

- using information wisely for the benefit of others.

\subsection{The sociocultural perspective}

The sociocultural perspective emphasizes the situated nature of learning and focuses on the relationship between individuals and various forms of collective practices, which may be defined as ways of understanding and doing things in the world, or, in other words, as socially structured and structuring patterns and resources that form the core of everyday life activities (Thorne, 2013). Such practices are embodied in communities of practice, which are groups of people who share similar goals and interests. They employ common practices, work with the same tools, and use a common language. In a community of practice, we learn not only the rules for the performing of an actual practice, but also acquire information required to determine which practices and knowledge that are deemed legitimate. This tacit information is coded and determined by the community, reflecting its history, assumptions, beliefs, values, and rules (Lloyd, 2010).

Over the course of learning, we interact with culturally constructed tools of practice, such as objects, signs, symbols, language, and technologies; accordingly, the sociocultural theory focuses on tool-based IL practices and does this within the context of learning communities. As learning is connected to specific situations and practices, following sociocultural approaches involves questioning the generic nature of acquiring IL (Limberg et al., 2012). While it accepts the broad framework of socially contextualized learning experience, the sociocultural approach may help in developing educational practices that move the perceptions and experiences of the individual learner to the center of educational practice (Talja \& Lloyd, 2010).

From a sociocultural perspective, IL is conceptualized as a collective practice occurring in complex social realities (Lloyd, 2012). It situates learning in a collaborative environment where it is related to social events and interactions with other people, objects, and events. This is a constructivist approach, but instead of emphasizing the role of the individual, it highlights social relations, community, and culture (Wang et al., 2011).

\subsection{The discourse analytic perspective}

Discourse analysis is heavily influenced by the work of Michel Foucault, for whom the central issue was to uncover the mechanisms in which social reality is produced. By "capturing the socially and culturally shaped ways of understanding information competencies and information practices" (Limberg et al., 2012, 110), discourse analysis recognizes language as central to social life, and a key to functioning in a society (Walton \& Cleland, 2017). 
From this perspective, the word "discourse" may simply refer to groups of linguistic signs that expresses what has been said or written. The socio-constructivist understanding is based on the following premise:

the meaning of words arises from their use and at its core privileges the role of language as a practice and assigns it centre stage for the creation of knowledge and the negotiation of truths (Haider \& Bawden, 2007, 537).

Social realities are formed through discourses. Therefore, discourse can be understood as

a productive practice, which obeys specific rules, is generative of knowledge and related to a particular field of use which, through discourse, is related to other fields and to other practices (Haider \& Bawden, 2007, 540).

The sociocultural and the discourse analytic perspectives are similar insofar as they both portray learning as a social activity that uses tools, practices, and conditions for meaning-making (Pilerot, 2016). The discourse analytic perspective focuses on identifying broader historical discourses of information literacy which will further the understanding of how interpretive repertoires vary. It also demonstrates that IL is constructed differently in different conversational contexts.

Discourse analysts do not accept information competences as uncontested phenomena, and therefore they study the interpretive repertoires, through which people ascribe meanings to information competencies and practices. They define discourses as systems of statements, i.e., sets of interlinked claims, assumptions, and meanings. It is presumed that we are users of already existing discourses, expressions, and conceptual frameworks; thus we accept implicit claims about the nature of information, even if we have not consciously scrutinized them and concluded that they are truthful or valid (Limberg et al., 2012). In general, however, this perspective shares several premises with phenomenographic and sociocultural approaches.

The comparison of the three approaches discussed above, done by Limberg, Sundin and Talja (2012) shows that phenomenography focuses on different patterns of experiencing information literacy. The focus of the sociocultural theory is the study of information literacy practices within specific contexts and communities. Discourse analysis aims to identify broad historical discourses. Their priorities bring in different understandings that define information literacy, i.e., variation in people's experiences, people's practices within specific communities, and variation in interpretive repertoires, respectively.

Based on social constructionist views as they are, these approaches might be criticized for their emphasis on the social construction of human realities and underestimating the role of the individual (Palmaru, 2016). This issue might be a subject of further discussion, especially if we accept that learning is inconceivable without learners' understanding of prior knowledge (Salisbury \& Karasmanis, 2011).

Nonetheless, these approaches offer tools for studying the impact of new technologies and digital media (especially social media) on conditions for learning in contemporary society. Both phenomenographic and sociocultural theories are explicitly grounded in theories of learning, therefore they reproduce the pedagogical perspective, as related to information literacy. The sociocultural perspective pays more attention to mediation by digital and other tools, while phenomenography and discourse analysis are more directly interested in analyzing experiences and interpretations not specifically based on theoretical assumptions about the use of various tools (Limberg et al., 2012). 


\section{A cognitive model of information literacy}

The approaches discussed above can be complemented by a cognitive model of information literacy, which not only bases on ideas taken from cognitive psychology and cognitive pedagogy, but also refers to the theories of representation, thus engaging with the concept of information-as-process. Understood as the act of informing, this concept - alongside with information-as-knowledge and information-as-thing (Buckland, 1991) - is an important and relatively well-known "building block" of information science.

Any cognitive model approaches information and knowledge in a relatively traditional manner - which does not mean that it is simplistic.

As its starting point, we can take the opinion of Machlup (1962) that knowledge and information are deeply related and united, despite the debates on the differences between them. This understanding might be complemented by Paisley's identification of information as a change in the structure of our thinking (Paisley, 1980), stating that information is every stimulus that changes the recipient's cognitive structure. This means that what is already known to the recipient cannot be identified as information, because it does not change the recipient's cognitive structure. Carl Popper's “Three Worlds” theory also contributed to the development of the cognitive approach. His "World 2" describes the internal, subjective mental state of an individual including their personal knowledge (Popper, 1979). As Bawden and Robinson (2016) argue, we might see that the concept of information-as-process already mentioned above - encompasses information changing a person's knowledge, and thereby addresses the same issue. Following this line of thought we might see information as interpreted data, facts, phenomena, events, i.e., the result of certain reflective procedures on data, often called cognitive procedures, studied by cognitive psychology and cognitive pedagogy. Such procedures and the results of cognition in our mentality give rise to representations, and therefore - if we wish to understand the nature of information - we have to reckon with the theories that describe this process of representation.

Representations take two forms: informational knowledge (knowing what) and operational knowledge (knowing how). This implies that developing information literacy could rely on supporting the development of these representations.

The growth of informational knowledge involves above all the emergence of psychic representations. Verbal information (knowledge) is structured: it unfolds on the level of data, names, labels; simple statements, facts; stories, descriptions; then, it achieves a higher level of integration, i.e., the level of rules, theories, and formal systems. This integrated system of information forms a network, while integration and networking are enabled by operational knowledge (Csapó, 1992; Eysenck \& Keane, 1997).

To support the development of informational knowledge in education, we may use a unified model constructed according to the following principles:

(1) It is necessary to make learners aware of the importance of selecting information before they engage in information processing, because their knowledge may represent objective or subjective reality. This selection should be directed by targeted and purposeful learning activities, and supported by teachers (including school-teachers and teaching staff members in higher education, as well as information professionals). The role of the teacher is therefore to construct a purposefully organized landscape for the learning activities supported by skilled and well-trained individuals, who 
became proficient in selecting information. As a result, the process of cognition might become more time-efficient, but more importantly, there is a possibility of a cognitive economics, enabling the learner saving up cognitive decision-making time on information processing if it is not useful for the particular learning activity.

(2) It is important for both the learners and the teacher to experience the difference between visual and propositional contents, as they can be used to solve different problems. The accessibility of a given type of content for a learner in a given learning context depends on the situation and the learner's aptitude. Different learning situations and learning communities, with different learning practices, experiences and tools, create different propositional or visual content in the cognition process, resulting in constantly changing information in the matrix of actors and activities (see the sociocultural model). The teacher is a professional actor supporting cognitive activities, who can also provide personalized visual or propositional content to the learner. The personal presence and expertise of the teacher guarantees the adaptive application of personalized instructions, explanations, representations and models.

(3) The process of structuring verbal information needs to be coordinated, that is to say, teachers need to support and control the creation of concepts. They also regulate the formation of statements and histories in order to obtain conventional knowledge, mediated by the school, and by teachers. Taken widely, all these are understood as constituents of the given learning environment.

(4) As a result, schools play an instrumental role in introducing students to story-telling, as teachers help them to discover rules and recognize the principles as quickly and efficiently as possible.

(5) The learner should be able to distinguish between elementary information (statements) and complex information (principles) to decide what kind of information is needed to solve a given problem in a purposeful and economical way. In this process, the professional support of the teacher is, again, indispensable.

(6) Being communicative spaces (information landscapes), schools may utilize purposeful planning and teacher's coordination, can store structured groups of concepts, events, series of events, imagery, situations, relationships, or even objects (e.g. when performing a physical experiment) in the form of common representations.

(7) Coordinated by their teachers, students are acquainted with scenarios (stereotypic series of events). They try them out and become accustomed to them, which makes their daily life activities easier and helps them to develop methods of independent knowledge acquisition in the form of searching for sources, evaluating them, analyzing and solving problems.

(8) Theories, formal systems and networks may emerge from long-standing learning activities. Their development is the result of coordinated learning activities, the effort of the teachers supporting the learning process, and, above all, of students' personal psychic operations, as well as their task and problem-solving activities.

The development of informational knowledge described above is not possible without the functioning of the operational knowledge, i.e., the performance of the representations. This is determined by skills, as well as task-solving and problem-solving abilities. Representation - forming a system of informational knowledge the course of a cognitive 
process - materializes in operations analysis, synthesis, enhancement, comparison, abstraction, and generalization. Skill-level, automated operations enable the formation of representations, which are carried on in the process of cognition. Thus, for example, problem-solving relies on all levels of thinking, and the theory-making process follows from all preceding stories, descriptions, and rules.

Operational knowledge is formed by cognitive operations producing information and by their integrated systems, the development of which is a pedagogical task. The most important goal is to develop the abilities that will help individuals to recognize their problem, as well as to identify, obtain and use all the necessary information about it in order to solve it (Csapó, 1992; Nagy, 2000).

The development of the operational knowledge in education can be facilitated according to the following principles:

(1) The teacher should plan to form and practice students' lower and higher psychic operations, such as analysis, searching association, synthesis, comparison, sequence recognition, identification, relationship detection, evaluation, application, restructuration, classification, organization, and distribution in a personalized, gradual and learning-specific way. By practicing psychic operations, the educators provide the learner with personalized information, thus initiating the process of reflecting on cognition, i.e., the experience of information processing becomes a personal experience for the cognizer (see the phenomenographic perspective).

(2) Students can follow tailor-made routines and operations in the teacher's presence and with their personalized support, and thus information can be delivered in a subject - and problem-specific form until they can identify actions that should be taken and are able to perform them flawlessly. This is the level of informational skills where recognition and execution are automatic.

(3) Diverse paths of intellectual activities should be purposefully planned, practiced, and implemented by the teacher in order to support the learners' ability to draw conclusions and analogies, as well as their ability to practice the ways of processing information by induction and deduction.

(4) The teacher should confront the students with personalized problem situations that inspire not only the development of informational knowledge, but also gradually reveal their cognitive abilities and creativity.

(5) Offering support to the students should include raising consciousness of their personal learning activities and self-reflection, as this is the only way to develop metacognition and conscious planning of information.

Finally, the acquisition of information and the development of informational knowledge is indispensable if the individual is motivated to acquire the information, to persevere in the information processes in which their information culture develops, and to have a continuous need for information and knowledge acquisition. However as Materska (2014) argues, people do not always invest their full mental capacities in the tasks of information acquisition and evaluation. Individuals' behavior is adaptive, i.e., they seek an optimal balance between cognitive effort and desired outcomes (Simon, 1979). Similarly to other Internet information seekers, most people - more or less unconsciously - resort to satisficing, as they do not use all their cognitive resources to obtain optimal outcomes, but seek just enough (good enough) resources. 
In the last section of this paper, we have emphasized cognitive pedagogical approaches. Besides the apparent complexity of cognitive processes, related to acquisition and development of information literacy, cognitive approaches should have their place in teaching of information literacy. They do not have to replace the current approaches, but they may certainly complement them. Moreover, as far as principles are concerned, the strict exclusivity of approaches does not seem to be beneficent to any scholarly enterprise.

\section{Conclusion}

As Todd (2017) put it, there is little exploration of what constitutes meaningful pedagogy of IL, and therefore there is a need for further discussion of the application of theories of learning and principles of pedagogical design. This study of a cognitive approach to pedagogy is meant to contribute to this undertaking.

This paper discussed three theoretical perspectives applicable to IL, as a part of a wider scholarly turn "from observation to participation, from documents to communities" (Špiranec et al., 2016, 249). Indeed, concepts, such as communities of practice and learning communities feature often in texts that employ phenomenographic, sociocultural, and discourse analytical approaches.

We have argued that these approaches, combined with a cognitive model (which this paper also discussed) promise a solid and novel theoretical basis for information literacy in educational settings, as they offer different, but interconnected insights into various levels of information literacy.

We also stressed that achieving efficient education in information literacy is impossible without situating it in the theoretical context of information science. To establish the relation between information science and our study, we discussed some pertinent issues.

If we ask the question if it is possible to construct an information literacy model or framework unifying all other information literacy models, there are no obvious answers. Nonetheless, we can be confident that we will witness further developments in learning and teaching, and changes in the relationships with other literacies (Onyancha, 2020).

There seems to be no argument against the proposition that questioning is the holy grail of information literacy (Walton, 2017), no matter if we ask questions regarding the trustworthiness, objectivity, and reliability of information, or question these qualities in any online communication, particularly the interactions in social media. Questioning has been always crucial, but it undeniably became particularly urgent in the post-truth society. Lifelong learning and a mind-set based on questioning help to build personal cognitive firewalls against fake news and related phenomena.

\section{Acknowledgement}

The authors express their gratitude to the anonymous reviewers for their constructive and detailed comments on the manuscript of this paper. 


\section{References}

AASL. (1998). Information Power. Building Partnership for Learning. American Association of School Librarians, Association for Educational Communications Technology, Chicago, IL: American Library Association.

Aharony, N., Limberg, L., Julien, H., Albright, K., Fourie, I., Bronstein, J. (2017). Information Literacy in an Era of Information Uncertainty. Proceedings of the Association for Information Science and Technology, 54(1), 528-531, https://doi.org/10.1002/pra2.2017.14505401063

ALISE. (2016). ALISE Research Taxonomy [online]. Association for Library and Information Science Education [26.09.2020], https://www.alise.org/research-taxonomy

Bawden, D. (2015). On Not Being a Weak Discipline [online]. The Occasional Informationist [14.09.2020], https://theoccasionalinformationist.com/2015/07/06/on-not-being-a-weak-discipline/

Bawden, D., Robinson, L. (2009). The Dark Side of Information: Overload, Anxiety and Other Paradoxes and Pathologies. Journal of Information Science, 35(2), 180-191, https://doi. org/10.1177/0165551508095781

Bawden, D., Robinson, L. (2016). Super-Science, Fundamental Dimension, Way of Being: Library and Information Science in an Age of Messages. In: Kelly M. \& Bielby J. (eds.). Information Cultures in the Digital Age (pp.31-43). Springer VS, Wiesbaden, https://doi.org/10.1007/978-3-658-14681-8_2

Bruce, C. S. (1997). Seven Faces of Information Literacy. Blackwood: Auslib Press.

Bruce, C. S. (2016). Information Literacy Research: Dimensions of the Emerging Collective Consciousness. A reflection. Australian Academic E Research Libraries, 47(4), 239-244, https://doi. org/10.1080/00048623.2016.1248236

Buckland, M. (1991). Information as Thing. Journal of the American Society for Information Science, 42(5), 351-360, https://doi.org/10.1002/(SICI)1097-4571(199106)42:5<351::AID-ASI5>3.0.CO;2-3

CILIP. (2018). CILIP Definition of Information Literacy [online]. CILIP. The Library and Information Association [14.09.2020], https://infolit.org.uk/ILdefinitionCILIP2018.pdf

Csapó, B. (1992). Kognitív pedagógia. Budapest: Akadémiai Kiadó.

Dora, M., Kumar, H. A. (2019). National and International Trends in Library and Information Science Research: A Comparative Review of the Literature [online]. IFLA Journal, First Published December 2019 [14.09.2020], https://doi.org/10.1177/0340035219886610

Eysenck, M. W, Keane, M. T. (1997). Kognitív pszichológia. Budapest: Nemzeti Tankönyvkiadó.

Forster, M. (2016). Phenomenography: A Methodology for Information Literacy Research. Journal of Librarianship and Information Science, 48(4), 353-362, https://doi.org/10.1177/0961000614566481

Haider, J., Bawden, D. (2007). Conceptions of "Information Poverty" in LIS: A Discourse Analysis. Journal of Documentation, 63(4), 534-557, https://doi.org/10.1108/00220410710759002

Hobbs, R. (2010). Digital and Media Literacy: A Plan of Action. A White Paper on the Digital and Media Literacy Recommendations of the Knight Commission on the Information Needs of Communities in a Democracy. Washington, DC: The Aspen Institute.

Koltay, T. (2015). Data Literacy: In Search of a Name and Identity. Journal of Documentation, 71(2), 401-415, https://doi.org/10.1108/JD-02-2014-0026

Koltay, T., Špiranec, S., Karvalics, L (2016). Research 2.0 and the Future of Information Literacy. Oxford: Chandos Publishing.

Lau, J. (2013). Conceptual Relationship of Information Literacy and Media Literacy. In: A. Lee, J. Lau, T. Carbo \& N. Gendina (eds.). Conceptual Relationship of Information Literacy and Media Literacy in Knowledge Societies (pp. 76-91). Paris: UNESCO.

Lee, A. Y., So, C. Y. (2014). Media Literacy and Information Literacy: Similarities and Differences. Comunicar, 21(42), https://doi.org/10.3916/C42-2014-13

Limberg, L., Sundin, O., Talja, S. (2013). Three Theoretical Perspectives on Information Literacy. Human IT: Journal for Information Technology Studies as a Human Science, 11(2), 93-130. 
Livingstone, S., van Couvering, E. J., Thumin, N. (2008). Converging Traditions of Research on Media and Information Literacies: Disciplinary and Methodological Issues. In: J. Coiro, M. Knobel, C. Lankshear \& D.J. Leu, (eds.). Handbook of Research on New Literacies (pp. 103-132). New York: Routledge.

Lloyd, A. (2006). Information Literacy Landscapes: An Emerging Picture. Journal of Documentation, 62(5), 570-583, https://doi.org/10.1108/00220410610688723

Lloyd, A. (2010). Information Literacy Landscapes: Information Literacy in Education, Workplace and Everyday Contexts. Oxford: Chandos Publishing.

Lloyd, A. (2012). Information Literacy as a Socially Enacted Practice: Sensitising Themes for an Emerging Perspective of People-in-Practice. Journal of Documentation, 68(6), 772-783, https:// doi.org/10.1108/00220411211277037

Lloyd, A. (2017). Information Literacy and Literacies of Information: A Mid-Range Theory and Model. Journal of Information Literacy, 11(1), 91-105, https://doi.org/10.11645/11.1.2185

Mackey, T. P., Jacobson, T. E. (2011). Reframing Information Literacy as a Metaliteracy. College E Research Libraries, 72(1), 62-78, https://doi.org/10.5860/crl-76r1

Machlup, F. (1962). The Production and Distribution of Knowledge in the United States. Princeton NJ: Princeton University Press.

Marcum, J. W. (2002). Rethinking Information Literacy. Library Quarterly, 72(1), 1-26, https://doi. org/10.1086/603335

Materska, K. (2014). Information Heuristics of Information Literate People. In: S. Kurbanoğlu, S. Špiranec, E. Grassian, D. Mizrachi \& R. Catts (eds.). Information Literacy, Lifelong Learning and Digital Citizenship in the 21st Century (pp. 59-69). Springer, Cham, https://doi.org/10.1007/9783-319-14136-7_7

Morrison, C., Secker, J. (2017). Understanding Librarians' Experiences of Copyright: Findings from a Phenomenographic Study of UK Information Professionals. Library Management, 38(6/7), 354-368, https://doi.org/10.1108/LM-01-2017-0011

Nagy, J. (2000). XXI. század és nevelés. Budapest: Osiris.

New London Group (1996). A Pedagogy of Multiliteracies: Designing Social Futures. Harvard Educational Review 66(10), 60-92, https://doi.org/10.17763/haer.66.1.17370n67v22j160u

Onyancha, O. B. (2020). Knowledge Visualization and Mapping of Information Literacy, 1975-2018. IFLA Journal, 46(2), 107-123, https://doi.org/10.1177/0340035220906536

Paisley, W. (1980). Information and Work. In: B. Dervin \& M. J. Voigt (eds.). Progress in Communication Sciences vol. 2 (pp. 113-165). New Jersey: Ablex.

Palmaru, R. (2016). Constructivism as a Key Towards Further Understanding of Communication, Culture and Society. Constructivist Foundations, 12(1), 30-38.

Pfaff-Rüdiger, S., Riesmeyer, C. (2016). Moved into Action. Media Literacy as Social Process. Journal of Children and Media, 10(2), 164-172, https://doi.org/10.1080/17482798.2015.1127838

Pilerot, O. (2016). Connections Between Research and Practice in the Information Literacy Narrative: A Mapping of the Literature and Some Propositions. Journal of Librarianship and Information Science, 48(4), 313-321, https://doi.org/10.1177/0961000614559140

Pinto, M., Escalona-Fernández M.I., Pulgarín, A. (2013). Information Literacy in Social Sciences and Health Sciences: A Bibliometric Study (1974-2011). Scientometrics, 95, 1071-1094, https://doi. org/10.1007/s11192-012-0899-y

Popper, K. R. (1979). Objective Knowledge: An Evolutionary Approach (revised edition). Oxford, UK: Clarendon Press.

Robinson, L. (2009). Information Science: Communication Chain and Domain Analysis. Journal of Documentation, 65(4), 578-591, https://doi.org/10.1108/00220410910970267

Salisbury, F., Karasmanis, S. (2011). Are They Ready? Exploring Student Information Literacy Skills in the Transition from Secondary to Tertiary Education. Australian Academic and Research Libraries, 42(1), 43-58, https://doi.org/10.1080/00048623.2011.10722203 
Secker, J. (2018). The Revised CILIP Definition of Information Literacy. Journal of Information Literacy, 12(1), 156-158, http://dx.doi.org/10.11645/12.1.2454

Simon, H. A. (1979). Rational Decision Making in Business Organizations. The American Economic Review, 69(4), 493-513.

Špiranec, S., Banek Zorica, M. (2010). Information Literacy 2.0: Hype or Discourse Refinement? Journal of Documentation, 66(1), 140-153, https://doi.org/10.1108/00220411011016407

Špiranec, S., Banek Zorica, M., Kos, D. (2016). Information Literacy in Participatory Environments: The Turn Towards a Critical Literacy Perspective. Journal of Documentation, 72(2), 247-264, https://doi.org/10.1108/JD-06-2015-0072

Street, B. (1984). Literacy in Theory and Practice. Cambridge: Cambridge University Press.

Talja, S., Lloyd, A. (2010). Integrating Theories of Learning, Literacies and Information Practices. In: A. Lloyd \& Talja, S. (eds.). Practising Information Literacy, Bringing Theories of Learning, Practice and Information Literacy Together (pp. ix-xviii). Cambridge: Woodhead Publishing.

Thorne, S. (2013). Digital Literacies. In: M. Hawkins (ed.), Framing Languages and Literacies: Socially Situated Views and Perspectives (pp. 192-218). New York: Routledge.

Todd, R. J. (2017). Information Literacy: Agendas for a Sustainable Future. Journal of Information Literacy, 11(1), 120-136, https://doi.org/10.11645/11.1.2233

Walton, G. (2017). Information Literacy is a Subversive Activity: Developing a Research-Based Theory of Information Discernment. Journal of Information Literacy, 11(1), 137-155, https:// doi.org/10.11645/11.1.2188

Walton, G., Cleland, J. (2017). Information Literacy: Empowerment or Reproduction in Practice? A Discourse Analysis Approach. Journal of Documentation, 73(4), 582-594, https://doi.org/10.1108/ JD-04-2015-0048

Wang, L., Bruce, C., Hughes, H. (2011). Sociocultural Theories and Their Application in Information Literacy Research and Education. Australian Academic and Research Libraries, 42(4), 296-308, https://doi.org/10.1080/00048623.2011.10722242

Webber, S., Johnston, B. (2000), Conceptions of Information Literacy: New Perspectives and Implications. Journal of Information Science, 26(6), 381-397, https://doi.org/10.1177/016555150002600602

Whitworth, A. (2014). Radical Information Literacy: Reclaiming the Political Heart of the Information Literacy Movement. Oxford: Chandos Publishing.

\title{
Kompleksowe podejście interdyscyplinarne do modelowania kształcenia w zakresie edukacji informacyjnej
}

\begin{abstract}
Abstrakt
Cel/Teza: W artykule omówiono najważniejsze zagadnienia teoretyczne i ramy badawcze, które mogą służyć za podstawę do opracowania modeli kształcenia w zakresie edukacji informacyjnej. Koncepcja/Metody badań: W artykule dokonano przeglądu piśmiennictwa tematu od lat 90 . XX w. do obecnej chwili oraz zarysowano kontekst dyscyplinarny edukacji informacyjnej w celu zidentyfikowania koncepcji, które mogą okazać się przydatne w modelowaniu kształcenia w zakresie edukacji informacyjnej.

Wyniki i wnioski: W świetle konwergencji i pokrywania się znaczeń różnych koncepcji dotyczących kompetencji, niniejszy artykuł rozważa różne podejścia pedagogiczne - fenomenograficzne, socjokulturowe oraz analizę dyskursu - w celu połączenia ich z podejściem kognitywnym do kształcenia
\end{abstract}


w zakresie edukacji informacyjnej. Przegląd piśmiennictwa pokazuje, że wszystkie te podejścia mogą mieć wkład w podstawę teoretyczną kształcenia w zakresie edukacji informacyjnej w różnych grupach wiekowych i na różnych poziomach edukacji.

Oryginalność/Wartość poznawcza: Kształcenie w zakresie edukacji informacyjnej zostało przeanalizowane z perspektywy interdyscyplinarnej, z naciskiem na naukę o informacji i pedagogikę.

\section{Słowa kluczowe}

Edukacja informacyjna. Fenomenografia. Nauka o informacji. Pedagogika. Podejście dyskursu analitycznego. Podejście kognitywne. Podejście socjokulturowe.

Dr. habil. TIBOR KOLTAY, PhD is Professor and Independent Researcher, retired from Eszterházy Károly University, Hungary. His main interests are information literacy and other literacies, as well as Research Data Management. His most recent publication in this field is Quality of Open Research Data: Values, Convergences and Governance. Information, 11(4) (2020), https://doi.org/10.3390/info11040175

Contact to the Author:

tkoltay@freemail.hu

Eszterházy Károly University

Jászberény Campus

Rákóczi út 53, Jászberény, Hungary, H-5100

ENIKÖ SZÖKE-MILINTE, PhD is Associate Professor, Head of Vitéz János Teacher Training Center at Pázmány Péter Catholic University, Hungary. Her research focuses on media and communication education and teacher education. Her publications include Theory and Practice in Communication Course Books. Acta Didactica Napocensia, 6(3), 45-54. (2013) and Didactic Teaching Strategies for Successful Learning. Revista PedActa, 3(2), 49-57. (2013). Her Hungarian language monograph, titled Információ - média (tudatosság) - műveltség (Information - Media Awareness - Literacy) was published in 2020.

Contact to the Author:

szoke-milinte.eniko@btk.ppke.hu

Pázmány Péter Catholic University

Vitéz János Teacher Training Center

Piliscsaba, Egyetem u. 1, Hungary, H-2087 